\title{
PELAKSANAAN PEMBELAJARAN AKUNTANSI KELAS XI A1 PADA SMKN-1 KATINGAN HILIR
}

\author{
Oleh \\ Siti Sundari*, Endang Sri Suyati** \\ Email:endangsuyati@gmail.com
}

\begin{abstract}
This study aims to find out how the implementation of accounting learning, the subject under study is Vocational High School 1 Katingan Hilir. This study uses qualitative methods with descriptive research types, which are the subjects of this study are principals, accounting teachers, and students. Accounting class XI and Class XII are still referring to the KTSP curriculum, some important points obtained are: 1) the teacher prepares lesson plans as direction in the implementation of accounting learning activities, 2) pray before starting the lesson, 3) attend students, 4) identification of learners 'needs, 5) material delivered by using methods in carrying out competency examination assignments in each student's accounting book, 6) evaluating the achievement of students' learning goals consisting of skills in working on problems, neatness and accuracy. Based on the results of research found in the field that the implementation of accounting learning has not been maximal and the applied accounting subjects have not run optimally.
\end{abstract}

(C) Muhammadiyah University Palangkaraya

Keywords: learning, accounting subjects

\begin{abstract}
ABSTRAK
Penelitian ini bertujuan untuk mengetahui bagaimana pelaksanaan pembelajaran akuntansi, subjek yang diteliti adalah SMK Negeri 1 Katingan Hilir. Penelitian ini menggunakan metode kualitatif dengan jenis penelitian deskriptif, yang menjadi subjek penelitian ini adalah Kepala sekolah, guru akuntansi, dan peserta didik. Pembelajaran akuntansi kelas XI dan Kelas XII masih mengacu pada kurikulum KTSP, beberapa poin penting yang didapat yaitu: 1) guru menyiapkan RPP sebagai arahan dalam kegiatan pelaksanaan pembelajaran akuntansi, 2) berdo'a sebelum memulai pelajaran, 3) mengabsen peserta didik, 4) identifikasi keperluan peserta didik, 5) materi disampaikan dengan menggunakan metode dalam mengerjakan tugas ujian kompetensi yang ada di buku akuntansi masing-masing peserta didik, 6) evaluasi pencapaian tujuan belajar peserta didik yang terdiri atas kecakapan dalam mengerjakan soal, kerapian dan ketelitian. Berdasarkan hasil penelitian yang ditemukan dilapangan bahwa pelaksanaan pembelajaran akuntansi belum maksimal dan mata pelajaran akuntansi yang diterapkan belum berjalan dengan maksimal.
\end{abstract}

(CUniversitas Muhammadiyah Palangkaraya

Kata kunci : pembelajaran, mata pelajaran akuntansi 


\section{PENDAHULUAN}

Pendidikan bagi bangsa indonesia bukanlah hanya ditujukan pada segelitintir orang, akan tetapi ditujukan kepada seluruh warga Negara. Menurut Undang-Undang RI Nomor 20 Tahun 2003 tentang Sistem Pendidikan Nasioanal :

Pendidikan adalah usaha sadar dan terencana untuk mewujudkan suasana belajar dan proses pembelajaran agar peserta didik secara aktif mengembangkan potensi dirinya untuk memiliki kekuatan spritual keagamaan, pengendalian diri, kepribadian, kecerdasan, akhlak mulia, serta ketrampilan yang diperlukan oleh dirinya, masyarakat, bangsa, dan negara.

Berdasarkan pengertian tersebut, pendidikan harus diselenggarakan dengan sadar dan proses pembelajarannya direncanakan sehingga segala sesuatu yang akan dilakukan oleh guru dan peserta didik merupakan proses pembelajaran untuk mencapai tujuan yang telah ditetapkan, yaitu mengembangkan potensi peserta didik.

Seiring dengan kemajuan zaman serta perkembangan teknologi, manusia dibebankan serta di tuntut untuk dapat menyeimbangkan diri terhadap kemajuan tersebut agar tidak dinyatakan sebagai manusia yang tertinggal dalam segala hal. Upaya untuk menyeimbangkan diri tersebut harus diawali dengan adanya dasar ilmu pengetahuan, dan ilmu pengetahuan tersebut tentunya diperoleh melalui lembaga pendidikan baik formal maupun nonformal. Jalur pendidikan ini mempunyai jenjang pendidikan yang jelas, mulai dari pendidikan dasar, pendidikan menengah sampai pendidikan tinggi.

Selain berpengatahuan bermasyarakat juga dituntut untuk memiliki ketrampilan yang memadai untuk merespon kebutuhan industri ataupun dunia kerja. Untuk memenuhi adanya kebutuhan tersebut maka Sekolah Menengah Kejuruan (SMK) menempatkan diri sebagai tempat untuk memperoleh ilmu pengetahuan dan keterampilan yang beragam.

Seperti halnya sekolah menengah yang lain, SMK juga kini tumbuh dan berkembang, baik negeri maupun swasta, dan memiliki tujuan yang sama yaitu memberikan ketrampilan bagi anak didiknya dalam berbagai bidang keahlian dan ketrampilan. Salah satunya adalah SMK Negeri 1 Katingan Hilir yang merupakan sekolah kejuruan pertama dikabupaten Katingan.

Dalam menempuh pendidikan setiap individu memiliki perbedaan baik itu pola fikirnya, perbedaan dalam fisik, dan perbedaan dalam hal belajar yang mana masing-masing individu memiliki kelebihan dan kekurangan dalam menerima pelajaran yang di sampaikan oleh guru. Guru adalah sebagai fasilitator dan motivator maka guru hendaknya dapat megoptimalkan aktivitas belajar peserta didik, sehingga mampu menciptakan suasana belajar yang menyenangkan dan memotivasi peserta didik untuk belajar dengan baik dan bersemangat pada akhirnya bisa berdampak positif dalam pencapaian hasil belajar. Belajar tidak bisa 
dipaksakan oleh orang lain dan juga tidak bisa dilimpahkan kepada orang lain.

Aktivitas pelaksanaan pembelajaran akuntansi merupakan suatu kegiatan yang dilakukan untuk menghasilkan perubahan pengetahuanpengetahuan, nilai-nilai sikap, dan keterampilan pada peserta didik sebagai latihan yang dilaksanakan secara sengaja.

Moechtar (dalam Nafarin, 2004:1) bahwa: Accountings the art of recording, classifying, and summarizing in a significant manner and in terms of money, transactions and event which are, in part least, of financial character and interpreting the result thereof. (Akuntansi adalah seni pencatatan, penggolongan, dan peringkasan dengan suatau cara yang berarti dan dalam nilai uang kejadian dan transaksi yang paling sedikit atau sebagian, bersifat keuangan, dan atas penafsiran hasilnya).

Dalam pelaksanaan Pembelajaran akuntansi tak selalu berjalan dengan maksimal, tidak jarang peserta didik merasa bosan dan kesulitan memahami pelajaran karena metode mengajar yang digunakan oleh guru, hal-hal demikian harus diperhatikan dalam pembelajaran akuntansi untuk mencapai suatu tujuan yang telah direncanakan dalam pendidikan, dalam suatu pembelajaran seorang guru masih sering menggunakan metode ceramah, hal tersebut sangat berpengaruh pada keaktifan peserta didik.

Dari observasi awal yang peneliti lakukan di SMKN - 1 Katingan Hilir khususnya Kelas XI Akuntansi 1, dimana proses belajar mengajar berlangsung masih ditemukan beberapa kelemahan. Masalah yang paling banyak yaitu mereka mengalami kesulitan dalam penguasaan materi. Hal ini dikarenakan guru masih sering menggunakan metode ceramah, sebagian dari peserta didik masih belum memahami pelajaran yang dijelaskan. Berdasarkan pengamatan yang dilakukan pada saat kegiatan pembelajaran akuntansi, peserta didik tidak sepenuhnya memperhatikan penjelasan guru, dikarenakan bosan dengan aktivitas mendengarkan, sehingga proses pembelajaran dirasa kurang menyenangkan bagi peserta didik. Hal ini tampak sangat berpengaruh terhadap pencapaian hasil belajar peserta didik pada kelas XI Akuntansi 1 di SMKN- 1 Katingan Hilir yang pencapaian nilainya masih banyak yang belum memenuhi Kriteria Ketuntasan Minimal (KKM) yaitu 75.

Berdasarkan fenomena diatas maka peneliti tertarik untuk melakukan penelitian dengan mengangkat judul Pelaksanaan Pembelajaran Akuntansi (Studi Kasus SMK Negeri 1 Katingan Hilir).

Berdasarkan paparan di atas tujuan penelitian ini adalah:

1. Untuk mengetahui bagaimana pelaksanaan pembelajaran Akuntansi pada SMKN-1 Katingan Hillir.

2. Untuk mengetahui aktivitas peserta didik dalam pembelajaran Akuntansi kelas XI Akuntansi 1 SMKN-1 Katingan Hillir. 


\section{METODE PENELITIAN}

Penelitian ini peneliti menggunakan pendekatan kualitatif. Menurut Bogdan dan Taylor (Moleong, 2012:4) penelitian kualitatif adalah prosedur penelitian yang menghasilkan data deskriptif berupa kata-kata tertulis dan lisan dari orang-orang dan perilaku yang dapat diamati.

Sedangkan menurut Denzim dan Lincoln (dalam Moleong, 2009:5) menyatakan bahwa penelitian kualitatif adalah penelitian yang menggunakan latar alamiah, dengan maksud menafsirkan fenomena yang terjadi dan dilakukan dengan jalan melibatkan metode yang ada.

Sejalan dangan itu Sugiyono (2010:15) menyebutkan: Metode penelitian kualitatif adalah metode penelitian yang berlandaskan pada filsafat postpositivisme, digunakan untuk meneliti pada kondisi obyek yang alamiah, (sebagai lawanya adalah eksperimen) dimana peneliti adalah sebagai intrumen kunci, snowball, teknik pengumpulan dengan trianggulasi (gabungan), analisis data bersifat induktif/kualitatif, dan hasil penelitian kualitatif lebih menekankan makna daripada generalisasi.

Pada penelitian ini peneliti menyelidiki peristiwa-peristiwa sebagaimana adanya seperti terjadi secara alamiah. Pemilihan pendekatan kualitatif dengan ini juga memiliki kesesuaian dengan fokus penelitian yang akan diteliti yang pada hakekatnya ialah mencari tahu tentang Aktivitas pembelajaran akuntansi peserta didik yang saat ini sedang terjadi di kelas XI
Akuntansi 1 SMK Negeri 1 Katingan Hilir yang dikaji menggunakan peserta didik dan guru Akuntansi sebagai sumber data/informan yang mendasari pemilihan penelitian.

Jenis penelitian ini menggunakan jenis penelitian kualitatif deskriptif yang artinya penelitian ini berusaha mendeskripsikan suatu gejala, peristiwa, dan kejadian saat sekarang dengan maksud memperoleh data yang berbentuk kata, kalimat, skema, dan gambar.

\section{HASIL DAN PEMBAHASAN}

Telah diuraikan pada bagian temuan penelitian diatas bahwa pelaksanaan pembelajaran akuntansi satu kali pertemuan selama 3 jam 30 menit untuk mata pelajaran akuntansi kelas XI akuntasni 1. Menurut penjelasan yang disampaikan guru kepada peneliti pada saat wawancara bahwa sebelum pelaksanaan pembelajaran akuntansi guru terlebih dahulu memberikan arahan bagaimana caranya agar peserta didik dapat menerima pelajaran akuntansi dengan baik, akan tetapi kenyataan dilapangan arahan serta bimbingan seorang guru akuntansi sangat jarang terjadi hal ini mengakibatkan kurang efektifnya pelaksanaan pembelajaran akuntansi yang sedang berlangsung dikelas karena banyak peserta didik yang masih belum memahami penjelasan dari guru.

\section{Perencanaan Pelaksanaan \\ Pembelajaran \\ Sebelum melaksanakan proses} pembelajaran maka setiap guru wajib membuat rencana pembelajaran karena 
rencana mengajar merupakan pedoman guru dalam pembelajaran. Dalam membuat rencana pembelajaran yang efektif, dan berhasil guna, dituntut untuk memahami berbagai aspek yang berkaitan dengan pengembangan rencana pembelajaran, baik berkaitan dengan hakekat, fungsi, prinsip, maupun prosedur pengembangan rencana pembelajaran, serta cara mengukur efektifitas rencana pembelajaran. Perencanaan merupakan proses penyusunan sesuatu yang akan dilaksanakan untuk mencapai tujuan yang telah ditentukan. Pelaksanaan perencanaan tersebut dapat disusun berdasarkan kebutuhan dalam jangka waktu tertentu sesuai dengan keinginan pembuat perencanaan. Namun yang lebih utama adalah perencanaan yang dibuat harus dapat dilaksanakan dengan mudah dan tepat sasaran. Keberhasilan suatu proses pembelajaran di tentukakan oleh perencanaan yang matang. Perencanaan yang dilakukan dengan baik, maka setengah keberhasilan sudah dapat tercapai, setengahnya lagi terletak pada pelaksanaan.

2. Pelaksanaan Pembelajaran Akuntansi

Pelaksanaan pembelajaran akuntansi di kelas XI Akuntansi 1 dilaksanakan berdasarkan kurikulum yang digunakan di SMK-N 1 Katingan Hilir yakni kurikulum tingkat satuan pendidikan ( KTSP ). Penggunaan Kurikulum adalah sebagai acuan pembelajaran sebagai mana yang disampaikan oleh pendapat Hasan (dalam Kunandar, 2010:124)
Kurikulum dapat diartikan sebagai dokumen atau rencana tertulis mengenai kualitas pendidikan yang harus dimiliki oleh peserta didik mengenai suatu pengalaman belajar. Sedangkan menurut pendapat I Djoko Susilo (2009:83) kurikulum dapat diartikan sebagai berikut: Sebagai sejumlah kegiatan yang diberikan kepada siswa, kegiatan ini sebagaian besar adalah menyajikan bahan pelajaran agar siswa menerima, menguasai dan mengembangkan bahan pelajaran itu. Jelaslah bahan pembelajaran itu mempengaruhi belajar siswa. Kurikum yang kurang baik berpengaruh tidak baik terhadap belajar. Menurut pendapat diatas dapat diketahui bahwa kurikulum adalah sebagai bahan tertulis mengenai suatu kualitas pendidikan yang seharusnya di miliki oleh peserta didik dalam kehidupan sekolah, kurikulum tidak hanya sebagai bahan pelajaran tetapi termasuk seluruh kehidupan di dalam kelas dimana hubungan dengan guru, metode mengajar guru dan hubungan guru antar peserta didik. Menurut penjelasan yang disampaikan guru kepada peneliti pada saat wawancara bahwa sebelum melaksanaan pembelajaran akuntansi guru terlebih dahulu memberikan arahan bagaimana caranya agar peserta didik dapat menerima pelajaran akuntansi dengan baik, akan tetapi kenyataan dilapangan arahan serta serta bimbingan seorang guru akuntansi sangat jarang terjadi hal ini mengakibatkan kurang efektifnya pelaksanaan pembelajaran akuntansi yang sedang berlangsung dikelas. 
Dalam mengacunya pada kurikulum maka guru akuntansi mengembang suatu pembelajaran pada mata pelajarn akuntansi dengan Rencana Pelaksanaan Pembelajaran ( RPP ). Dalam RPP guru akuntansi menyesuaikan dengan materi dan kondisi peserta didik, yang mana pelaksanaan pembelajaran akuntansi terkadang tidak sesuai dengan RPP yang telah dibuat oleh guru akuntansi. Hal tersebut disebabkan kemampuan peserta didik dalam memahami pelajaran akuntansi. Sarana dan prasarana sebagai penunjang penerapan kurikulum KTSP seperti buku-buku materi pelajaran atau pun media pembelajaran yang lain pun telah tersedia tetapi yang menjadi masalah yang mengakibatkan kurikulum tersebut tidak berjalan dengan sempurna yaitu dari segi tenaga pengajar yang masih belum benar-benar mamanfaatkan fasilitas yang tersedia disekolah hal ini disebabkan karena guru hanya terpaku pada metode pengajaran yang digunakan disekolah tersebut. Tidak dimanfaatkan sarana dan prasarana yang ada dalam pelaksanaan proses pembelajaran akuntansi dapat mengakibatkan kurang efektifnya proses belajar mengajar yang pada akhirnya akan menyebabkan kurang maksimalnya pencapaian tujuan pembelajaran yang telah ditetepkan. Sejalan dengan hal tersebut, Brive,Jhonson, Young, berpendapat bahwa : Alat-alat bantu pendidikan yang tersedia secara tepat baik dalam jumlah maupun dalam mutu sangat membantu kelancaran dan keberhasilan proses pendidikan.Efektifitas kegunaan setiap alat bantu pendidikan tergantung pada persiapan pendidik dan si terdidik dalam menggunakan alat bantu tersebut. (Young dalam Endang Soenarya,2006 :30). Sebelum melaksanakan proses belajar mengajar, semestinya segala sesuatu yang berkaitan dengan kebutuhan pelaksanaan pembelajaran akuntansi baik dari segi guru, peralatan dan media-media pembelajaran lain-lain haruslah dipersiapkan dengan baik dan tepat sesuai dengan materi yang akan dibahas itulah sebabnya mengapa peran RPP sangat berguna dalam pelaksanaan pembelajan akuntansi dikelas sehingga tujuan kegiatan pembelajaran dapat tercapai dengan maksimal.

Sejalan dengan hal ini Udin Saiffulah, Wanata Putra berpendapat bahwa : Sumber-sumber belajar menjadi lima kategori, manusia, bukubuku perpustakaan, media masa, alam sekitar atau lingkungan, dan media pendidikan.karena sumber belajar adalah segala sesuatu yang dapat dipergunakan sebagai tempat dimana bahan pengajaran terdapat atau untuk seseorang. Udin Sarifudin, Winata Putra (dalam Saifful Bahri Djamarah). Jika ditinjau dari permasalahan yang ada dan kemudian dibandingkan dengan beberapa pendapat diatas maka dapat diambil kesimpulan bahwa proses pelaksanaan pembelajaran akuntansi masih belum berjalan dengan rencana serta perlu adanya peningkatan kreatifitas model pembelajaran atau metode pembelajaran dalam pelaksanaan pembelajaran akuntansi.

3. Penyampaian materi pelajaran akuntansi 
Penyampaian materi pelajaran akuntansi merupakan sebuah pelaksanaan pembelajaran akuntansi. Guru menyampaikan materi ajar kepada peserta didik untuk mencapai suatu kegiatan pengajaran yang telah ditetapkan, akan tetapi dalam penyampaiannya materi tanpa adanya strategi pembelajaran maka semua tidak akan berjalan sesuai dengan yang diinginkan. Menurut Kem ( Wina Sanjaya, 2010:126) : sstrategi pembelajaran adalah suatu kegiatan pembelajaran yang harus dikerjakan oleh guru dan siswa agar tujuan pembelajaran dapat dicapai dengan eektif dan efesien. Pada pelaksanaan mata pelajaran akuntansi di kelas XI A1 SMK Negeri 1 Katingan Hilir strategi yang diatas telah dilaksanakan oleh guru dan peserta didik., yang mana guru menyampaikan materi pelajaran dengan metode ceramah dan diskusi. Materi yang digunakan sesuai dengan materi yang akan disampaikan terkadang guru menggunakan Metode ceramah dan terkadang menggunakan metode diskusi dan tanya jawab. Agar tidak terkesan membosankan metode mengajar yang berupa ceramah dan tanya jawab yang digunakan oleh guru mata pelajaran akuntansi sebaiknya dikaitkan dengan kejadian sehari-hari. Hal- hal tersebut didukung oleh penjelasan berikut ini : Peristiwa yang terjadi sehari-hari pun dapat digunakan sebagai titik awal. Hanya saja perlu diingat bahwa titik awal tersebut harus mempunyai kaitan dengan pokok bahsan baru. Yang berhubungan dengan topik baru dengan maksud agar siswa teringat kembali tentang apa yang sudah dipelajarinya atau kaitan permasalahan antar topik lama dengan yang baru. (Sardiman, 2011:196). Pelaksanaan pembelajaran akuntansi di kelas XI A1 yang ikuti oleh 33 peserta didik harus dikelola sedemikian rupa oleh guru mata pelajaran akuntansi. Tidak dapat dipungkiri bahawa terkadang ada saja peserta didik yang berusaha untuk mengganggu konsentarsi rekanrekannya. Jika itu terjadi didalam kelas tertentu saja tidak dapat dibiarkan karena dapat menganggu pelaksanaan pembelajaran akuntansi. Hal tersebut sebagaimana pendapat ahli dibawah ini : Aktivitas siswa yang bersifat negative dalam arti mengganggu berlangsungnya proses belajar mengajar perlu segera dihentikan. Siswa yang bermain sendiri atau mengganggu temannya yang lain atau berusaha menarik perhatian kelas, penting untuk mendapatkan perhatian guru. Ucapan yang dapat digunakan misalnya tentang perhatian, hangan ramai, dan lain sebagainya. Ucapan ucapan keji dan kotor tidak dapat dibenarkan dalam interaksi edukatif. (Sardiman, 2011:209). Dalam suatu kelas terdiri dari beberapa peserta didik dengan berbagai macam karakter serta perilaku. Demikian pula yang ada diruang kelas XI A1. Perebedaan karakter dan tingkah laku peserta didik harus disikapi secara bijaksana merupakan salah satu sikap yang harus dimiliki oleh guru termasuk diantaranya guru mata pelajaran akuntansi.

4. Penutupan Proses pembelajaran Penutup proses pembelajaran dimaksud untuk mengakhiri jalannya 
proses belajar mengajar pada hari itu dan akan dilanjutkan pada perrtemuan berikutnya lebih lanjutnya disebutkan bahwa kegiatan menutup pelajaran dijelasakan oleh pendapat User Usman dalam (Suryosubroto,2009:43)

1) Merangkum dan membuat garis besar persoalan yang dibahas

2) Mengosolidasikan perhatian siswa terhadap hal-hal yang diperoleh dalam belajar

3) Mengorganisasikan semua kegiatan pembelajaran yang telah dipelajari sehingga merupakan suatu kesatuan yang berarti dalam memahami materi.

Dan menurut pendapat lain juga menjelaskan menutup pelajaran dijelaskan dibawah ini : Isi dari mengakhiri pelajaran ini dapat berupa saran-saran misalnya meminta siswa untuk mempelajari kembali dirumah tentang bahan yang baru saja dipelajari. Atau mungkin siswa diminta di untuk mempelajari bahan selanjutnya dan pemberian tugas-tugas yang lain. ( sardiman, 2011:221). Pelaksanaan pembelajaran akuntansi ditutup ketika guru telah selesai menjelasakan materi pada hari itu. Sesuai dengan yang diungkapkan diatas bahwa setiap akhir pembelajaran guru memberikan soalsoal dan saran kepada peserta didik agar mempelajari kembali apa yang sudah disampaikan oleh guru.

\section{KESIMPULAN}

Berdasarkan hasil penelitian yang telah dilakukan oleh peneliti, maka dapat diambil kesimpulan yang berkaitan dengan pelaksanaan pembelajaran akuntansii di SMKN-1 Katingan Hilir diantaranya sebagai berikut :

1. Dalam pelaksanaan pembelajaran Akuntansi di kelas XI SMKN 1 Katingan Hilir masih menggunakan kurikulum KTSP, dan untuk kelancaran proses pembelajaran akuntansi guru menggunakan Rencana Pelaksanaan Pembelajaran (RPP) sebagai suatu persiapan pembelajaran akuntansi. Materi yang akan di sampaikan oleh guru akuntansi juga telah tercantum didalam buku paket akuntansi yang juga dimiliki oleh sebagian peserta didik.

2. Aktivitas pembelajaran akuntansi merupakan kegiatan yang dilakukan peserta didik saat mengikuti pengajaran yang sedang berlangsung tersebut masih belum maksimal, karena peserta didik masih kesulitan dalam memahami pelajaran akuntansi dan masih ada peserta didik yang belum bisa untuk diajak diskusi serius, karena dalam diskusi masih ada peserta didik yang kurang konsentrasi dan sarana pendukung pembelajaran masih kurang.

\section{DAFTAR PUSTAKA}

LeXIy J. Moleong, 2009. Metodologi Penelitian Kualitatif, Bandung : Remaja Rosdakarya

Lexy J, Moleong. (2012). Metodologi Penelitian Kualitatif. Bandung: Remaja Rosdakarya 
NERACA Jurnal Pendidikan Ekonomi, November 2017, Volume 3 Nomor 1(37-45)

http://journal.umpalangkaraya.ac.id/ejurnal/neraca

ISSN: 2477-607

Nafarin, (2004), Akuntansi pendekatan

Siklus dan Pajak untuk

Perusahaan Industri \& Dagang, Jakarta : Ghalia Indonesia

Sardiman, (2011). Interaksi dan Motivasi Belajar Mengajar. Jakarta: Raja Grafindo Persada
Sugiyono, (2010). Metode Penelitian Pendidikan. Bandung : Alfabeta Suryosubroto B. (2009), Proses Belajar Mengajar di Sekolah. Jakarta : PT. Rineka Cipta.

Undang-Undang RI No.20 Tahun 2003 Tentang Sisdiknas. Yogyakarta: Media Abadi 